\title{
Moving Mugabe's Mountain: Zimbabwe's Path to Arrears Clearance and Debt Relief
}

\section{Benjamin Leo and Todd Moss}

\begin{abstract}
Zimbabwe is embarking on a long, complex, and difficult journey to rebuild its economy, which has been

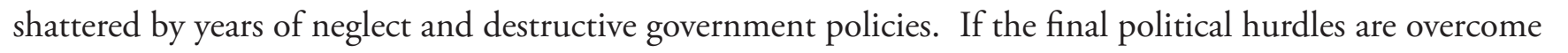
hopefully sooner rather than later-the new coalition government will be faced with making politically difficult decisions and addressing conclusively the economic ghosts of the past. One of those ghosts is more than $\$ 5$ billion owed to external creditors, of which nearly 80 percent is arrears. Clearing Zimbabwe's external debt arrears and securing comprehensive debt relief will be a critical step in eventual recovery. By doing so, the government will remove a crippling burden on its budget, investment climate, and overall macroeconomic environment. More important to the success of the coalition government, it will unlock hundreds of millions of dollars in new external assistance for critical reconstruction programs that will improve the Zimbabwean people's quality of life. This paper provides a detailed overview of the arrears clearance and debt relief processes. The purpose is to spark a debate in creditor capitals and hopefully to buttress the government's analytical foundation. With a strong dedicated team of experts—and support from relevant donor agenciesthe Zimbabwean government will one day conclusively address its crushing debt burden and proceed with the rebuilding of a once vibrant and proud nation.
\end{abstract}




\title{
Moving Mugabe's Mountain: Zimbabwe's Path to Arrears Clearance and Debt Relief
}

\author{
Benjamin Leo \\ Todd Moss
}

November 12, 2009

Benjamin Leo formerly served as Director for African Affairs at the National Security Council and in a number of positions at the U.S. Department of Treasury. Todd Moss is senior fellow at the Center for Global Development and former Deputy Assistant Secretary for Africa in the U.S. Department of State. The authors thank the Governments of Norway and Australia for financial support that allowed this work to be undertaken. We also thank Steve Radelet, John Williamson, colleagues at the African Development Bank, and several anonymous reviewers for input and comments on earlier drafts of this paper. The authors are solely responsible for any errors in fact or judgment.

This paper was made possible by financial support from the Norwegian Ministry of Foreign Affairs and the Australian Agency for International Development.

Benjamin Leo and Todd Moss. 2009. "Moving Mugabe's Mountain: Zimbabwe's Path to Arrears Clearance and Debt Relief." CGD Working Paper 190. Washington, D.C.: Center for Global Development. http://www.cgdev.org/content/publications/detail/1423217

Center for Global Development 1800 Massachusetts Ave., NW Washington, DC 20036

202.416 .4000

(f) 202.416 .4050

www.cgdev.org
The Center for Global Development is an independent, nonprofit policy research organization dedicated to reducing global poverty and inequality and to making globalization work for the poor. Use and dissemination of this Working Paper is encouraged; however, reproduced copies may not be used for commercial purposes. Further usage is permitted under the terms of the Creative Commons License.

The views expressed in this paper are those of the author and should not be attributed to the board of directors or funders of the Center for Global Development. 


\section{Overview}

Zimbabwe's current political impasse may make discussions about arrears clearance and debt relief for the country appear premature. Yet there are good reasons to think proactively about the steps ahead for both short-term arrears clearance and long-term debt relief. As of this writing, the power-sharing agreement remains formally in place which while highly imperfect - provides a window of opportunity for progress. While uncertain, it is still possible that good-faith actions by the key parties to the agreement could place the unity government back on track. This would force donors to either scramble to address the critical external debt and arrears issues or slow down Zimbabwe's reengagement process with the international financial community. Both issues entail long processes with multiple steps and complex sequencing. An agreed roadmap forward will enable the international community and Zimbabwean finance officials to act more quickly if positive and conclusive political movement occurs. In particular, the ability to act swiftly on arrears to the major international financial institutions will be critical to supporting momentum toward economic recovery and will itself help to reinforce political progress. Indeed, even the most pessimistic projections still recognize that Zimbabwe will one day transition back to democracy and require action on the inherited debt as an unavoidable component of national reconstruction.

The Zimbabwean finance ministry projects that reconstruction costs will exceed \$5 billion over time. ${ }^{1}$ This includes both short-term infusions to restart agricultural and manufacturing activity as well as rehabilitation of service delivery infrastructure (water, health, education, electricity). All of these sectors have been devastated by misguided government policies, under-funding, and outright corruption. Under its Short-Term Emergency Recovery Program (STERP), the coalition government already has taken aggressive steps to stabilize the economy, such as cash-based budgeting, dollarization, and removal of quasi-fiscal payments to un-competitive state-owned enterprises. Given the paucity of government revenues, external assistance will be critical to financing large reconstruction programs. Moreover, this assistance will help to improve business confidence in Zimbabwe's economy and facilitate foreign and domestic investment.

The coalition government, if it is to ultimately succeed, must address a number of haunting Mugabe-era legacies before achieving a comprehensive and clean break with the past. ${ }^{2}$ One key legacy is Zimbabwe's unsustainable external debt burden, which dwarfs the government's revenue base and impedes new donor assistance. Although the international financial institutions (IFIs) and bilateral donors largely ceased development assistance programs in 2000 after the Zimbabwean government defaulted on its loans, they are enormous relative to Zimbabwe's economy. Currently, Zimbabwe's external debt stock totals over $\$ 5$ billion - of which, roughly 80 percent is in arrears. External debt stands at a crippling 166 percent of gross domestic product and 320 percent of annual export receipts. Zimbabwe owes over $\$ 2$ billion to Paris Club creditors and $\$ 1.2$

\footnotetext{
${ }^{1}$ See Zimbabwe's Short-Term Emergency Recovery Program, March 2009, page 20.

${ }^{2}$ See also Todd Moss and Stewart Patrick, "After Mugabe: Applying Post-Conflict Recovery Lessons to Zimbabwe,” Africa Policy Journal, Harvard University, Spring 2006.
} 
billion to IFIs (World Bank, African Development Bank, and International Monetary Fund). It also has sizable debt obligations to non-traditional bilateral governments and commercial creditors.

The implications of this debt burden are significant. Over the medium term, demands from debt service will squeeze the budget for reconstruction programs and create an "overhang" that will deter private investors. Yet more worrying is the immediate impact: clearing loan arrears is a binding prerequisite for securing new IFI and bilateral donor assistance. Thus failing to deal with the arrears problem will immediately hinder efforts by the coalition government to access international assistance and restart the economy. Many potentially large creditors will be legally constrained to help Zimbabwe only through humanitarian assistance or through special (inherently much smaller) funds for fragile or post-conflict states. In addition, failing to act will only make the arrears problem worse. As laid out below, more payments are due in the coming months, which will only add to the total arrears stock. Time is of the essence given the lengthy processes laid out below - both for short-term arrears clearance and for long-term debt relief.

In this paper, we lay out the arrears clearance and debt relief processes that Zimbabwe will face over the coming months and years. We explain the sequencing and interlinkages between the relevant creditor stakeholders, including the Paris Club, IMF, World Bank, African Development Bank, commercial creditors, and non-traditional bilateral government such as China (see Appendix V for a summary of the arrears clearance and debt relief steps). The underlying objective is to support the Zimbabwe government's development of a robust external debt management strategy. Going forward, we strongly urge the authorities to assemble a dedicated team of experts within the Ministry of Finance and Prime Minister's office to tackle these issues immediately and for creditors to begin thinking now how to help Zimbabwe address its crushing external debt burden.

\section{IFI ENGAGEMENT - HISTORICAL OVERVIEW}

World Bank: Between 1980 and 1999, the World Bank provided assistance to Zimbabwe totaling nearly $\$ 1.6$ billion. Funding largely concentrated on the infrastructure, agriculture, and health sectors (see Appendix I for the complete list of past projects). The World Bank's hard-loan facility - the International Bank for Reconstruction and Development (IBRD) - provided 58 percent of the relevant financing for these programs. Zimbabwe had access to these market-based loans given its status as an "IDA-blend" country. ${ }^{3}$ The World Bank's concessional financing facility -the International Development Association (IDA) - provided the remaining 42 percent.

The World Bank suspended its lending program in 2000 after the Zimbabwean government went into arrears on loan repayments. Since then, the World Bank's role has been limited to technical assistance and analytical work focusing on macroeconomic

\footnotetext{
${ }^{3}$ See further explanation of IDA-blend status and ramifications in Section VI.
} 
policy, food security, agrarian reform, social sector delivery, infrastructure needs, and HIV/AIDS program support. In 2005, the World Bank prepared an Interim Strategy Note to address knowledge gaps, which has helped establish a baseline for the current donor reengagement - particularly in the transportation, health, education, and agricultural sectors.

African Development Bank: Since inception, the African Development Bank (AfDB) has provided assistance to Zimbabwe totaling over UA 729 million (roughly \$1.1 billion). ${ }^{4}$ Funding largely concentrated on the infrastructure, extractive industries, agriculture, and the financial sectors. The AfDB's hard-loan facility provided 89 percent of the relevant financing for these programs. The AfDB's concessional financing window, the African Development Fund (AfDF), provided the remaining 11 percent. Like the World Bank, the AfDB suspended its lending program in 2000 after the government went into arrears on existing loan repayments. Since the political agreement was reached last September, the AfDB has been actively engaged with the Zimbabwean government. It has provided technical assistance and is playing a leading advisory role on reconstruction planning and reengagement with the donor community.

International Monetary Fund: Between 1980 and 1999, the IMF implemented three staff-monitored programs in Zimbabwe (see Appendix II for additional details). Financial assistance totaled SDR 374 million (approximately $\$ 575$ million). ${ }^{5}$ Of this, the General Resources Account ${ }^{6}$, which is the IMF’s non-concessional window, provided approximately SDR 222 million (\$341 million) and the more concessional Poverty Reduction Growth Facility Trust Fund provided SDR 152 million (\$234 million).

Since February 2001, Zimbabwe has been in continuous arrears to the IMF and is the only country currently in protracted arrears to the PRGF Trust Fund. ${ }^{7}$ In December 2003, the IMF Managing Director and Board of Directors formally initiated procedures to expel Zimbabwe from the IMF due to continued arrears to the General Resources Account (GRA) and its cessation of any repayments that year. ${ }^{8}$ While the Board considered the compulsory expulsion on several occasions between 2003 and 2006, formal action was never taken. In the end, the Zimbabwean government avoided expulsion by clearing its GRA arrears (although not its PRGF arrears) through several payments in 2004, 2005, and 2006, which totaled SDR 117 million (\$181 million). However, the IMF Board decided to continue Zimbabwe's ineligibility for future GRA assistance. Moreover, the IMF kept in place the decisions taken to address Zimbabwe's continued arrears to the PRGF Trust Fund, including the: (1) declaration of noncooperation; (2) suspension of technical assistance; and (3) removal of Zimbabwe from the list of PRGF-ESF eligible countries.

\footnotetext{
${ }^{4}$ This utilizes the June 17 UA/USD exchange rate of 1.5374. Note the AfDB Group's UA has an equivalent exchange rate as the IMF's SDR.

5 This utilizes the June 17 SDR/USD exchange rate of 1.5374 .

6 The General Resources Account is the IMF's central account providing non-concessional loans to middleincome countries. The Poverty Reduction and Growth Facility (PRGF) provides assistance to low-income countries on a more concessional basis.

${ }^{7}$ IMF Press Release No. 06/45

${ }^{8}$ IMF Press Release No. 03/210
} 
Loan Arrears Accumulation: As noted above, the Zimbabwean government largely halted payments to the International Financial Institutions (IFIs) and other external creditors in 2000. By 2006, total external loan principal and interest arrears totaled \$3.0 billion (see figure 1 below). As of April 2009, IFI arrears had reached over $\$ 1.2$ billion. The World Bank accounts for \$673 million; the African Development Bank, \$438 million; and the IMF, \$134 million.

Figure 1 - Total Arrears Stock and Ratios: 2006, projected for 2011

\begin{tabular}{ccccccc}
\multicolumn{2}{c}{$\begin{array}{c}\text { Volume (US\$ billion) } \\
2006\end{array}$} & \multicolumn{2}{c}{ Arrears-to-GDP (\%) } & \multicolumn{2}{c}{ Arrears-to-exports (\%) } \\
\hline 3.0 & 2011 & \multicolumn{2}{c}{2006} & 2011 & 2006 & 2011 \\
\hline
\end{tabular}

Source: IDA (2007), Further Elaboration of a Systemic Approach to Arrears Clearance

IFI arrears will continue to accumulate in the coming years as additional principal and interest payments come due. For example, Zimbabwe will owe the IBRD and IDA roughly \$172 million in debt service payments between 2009 and 2012. ${ }^{9}$ Figure 2 below outlines IDA and IBRD estimated debt service payments falling due over time. The annual growth rate in World Bank arrears will average roughly 12 percent until 2012 when IBRD obligations taper off. After that, arrears will grow annually by about 6 percent. ${ }^{10}$ Repayment obligations to the African Development Bank will continue to compile in a similar fashion. This continued accumulation demonstrates the need to clear Zimbabwe's arrears as quickly as possible and to build a financial buffer into any relevant cost projections.

\begin{tabular}{|c|c|c|c|c|c|c|c|c|c|}
\hline \multirow[b]{2}{*}{ Year } & \multicolumn{7}{|c|}{ Figure 2 - Estimated World Bank Group Debt Service Payments } & \multicolumn{2}{|l|}{ Total } \\
\hline & Principal & Charges & Total & Principal & Charges & Total & Principal & Charges & Total \\
\hline 2009 & 17.7 & 4.1 & 21.8 & 9.8 & 2.4 & 12.2 & 27.5 & 6.5 & 34.0 \\
\hline 2010 & 30.2 & 6.2 & 36.4 & 13.2 & 3.2 & 16.4 & 43.4 & 9.3 & 52.8 \\
\hline 2011 & 27.6 & 3.9 & 31.5 & 13.2 & 3.1 & 16.3 & 40.8 & 7.0 & 47.8 \\
\hline 2012 & 17.4 & 2.0 & 19.4 & 15.6 & 3.0 & 18.6 & 33.0 & 5.0 & 38.0 \\
\hline Total & 108.5 & 17.4 & 125.9 & 440.5 & 36.3 & 476.8 & 549.0 & 53.7 & 602.7 \\
\hline 2009-2012 & 92.9 & 16.2 & 109.1 & 51.9 & 11.6 & 63.4 & 144.7 & 27.8 & 172.5 \\
\hline 2013-2037 & 15.7 & 1.2 & 16.8 & 388.7 & 24.7 & 413.4 & 404.3 & 25.9 & 430.2 \\
\hline
\end{tabular}

International Sanctions: During the 2000s, several countries - including the United States, European Union, and Australia - imposed targeted financial and travel sanctions against select members of Zimbabwe's former ruling party (ZANU-PF) for undemocratic activities and human rights abuses. By illustration, the United States has frozen U.S.-based assets of 137 individuals, 36 companies, and 28 farms through the

\footnotetext{
${ }^{9}$ These figures reflect balances as of May 31, 2009.

${ }^{10}$ IDA (2007). “Further Elaboration of a Systematic Approach to Arrears Clearance." p3.
} 
Office of Foreign Assets Control (OFAC). Moreover, U.S. entities or persons are prohibited from conducting business transactions with these entities or on their behalf. Lastly, the U.S. Department of State has imposed travel sanctions against a wide range of government officials. Currently, these measures remain in place. However none of these measures should have any direct effect on arrears clearance or debt relief since they are against individuals and firms, not the government itself.

The one potential exception is U.S. legislation, the 2001 Zimbabwe Democracy and Economic Recovery Act (ZDERA). ZDERA directs the U.S. representatives at the major financial institutions to oppose any new credits or debt relief to Zimbabwe until the U.S. President determines that certain conditions have been met. In practice, however, ZDERA has had no discernible impact on U.S. or IFI assistance programs as the reductions in credit have been based on arrears accumulation and deterioration in performance, rather than votes by the boards. Once the U.S. government makes a decision to actively support arrears clearance and debt relief for Zimbabwe, there may be some additional legislative action required to clear the way (see Appendix VII for additional detail on ZDERA).

\section{Recent Political ANd Economic Events}

March 2008 Elections and Provisional Government: In March 2008, Zimbabwe held presidential and parliamentary elections, which Movement for Democratic Change (MDC) candidate Morgan Tsvangirai won with an estimated 49.4 percent of the vote. ${ }^{11}$ Following widespread violence and political upheaval, Zimbabwe held a runoff election between Morgan Tsvangirai and Robert Mugabe in late June 2008. ${ }^{12}$ Citing voter persecution and intimidation, MDC President Tsvangirai withdrew from the runoff. Mugabe went on to win a landslide election - which again was internationally condemned as a flawed process - and retained the presidency. Following several months of mediation led by the Southern African Development Community (SADC), Tsvangirai and Mugabe reached a power-sharing agreement in September 2008. Under the agreement, Tsvangirai became Zimbabwe's Prime Minister overseeing the Council of Ministers with Mugabe retaining the presidency and control over the security forces. To date, several aspects of the agreement remain outstanding, such as the continued role of Reserve Bank Governor Gideon Gono and the appointment of Attorney General Johannes Tomana. Under the provisional agreement, the MDC gained the post of Finance Minister, to which Prime Minister Tsvangirai appointed his MDC party deputy Tendai Biti - a lawyer by training and key political and economic advisor.

Macroeconomic Stabilization Efforts: Under the auspices of the Short-Term Emergency Recovery Program (STERP), the Finance Ministry has taken a series of steps to stabilize the country's macroeconomic situation while still attempting to address pressing social service delivery needs. On the budgetary front, it has halted the Reserve Bank's quasi-

\footnotetext{
${ }^{11}$ The 49.4 percent figure is based on the compilation of results posted at each individual polling station. Official Zimbabwe Electoral Commission figures put Tsvangirai’s share at 47.8 percent compared to Mugabe's 43.2 percent. However, the international community raised significant concerns about the validity of these figures.

${ }^{12}$ Under the Zimbabwean constitution, an absolute majority is required to win the presidency.
} 
fiscal activities and introduced measures to bring the budget into balance (i.e., spending only what the government receives in revenues on a month-by-month basis). The Reserve Bank’s quasi-fiscal expenditures reached \$1.1 billion in 2008 (roughly 36 percent of GDP) ${ }^{13}$ and were directed for election-related expenses, grant transfers to parastatals, direct lending subsidies, subsidized purchase and distribution of agricultural equipment and inputs (fertilizer, seeds, fuel), and subsidized access to foreign exchange. These expenditures were financed through surrender requirements on export proceeds, confiscation of foreign currency-denominated bank deposits, intervention into the parallel exchange rate market, and especially expansion of the money supply. Up until the power-sharing agreement, the Reserve Bank's tentacles permeated and distorted nearly every aspect of the Zimbabwean economy.

The government also surrendered to widespread dollarization of the economy and abandoned the Zimbabwean dollar as the unit of exchange. It has established a multicurrency system with the South African rand operating as the reference currency. While the U.S. dollar remains widely used in transactions, including recent public sector wage payments, the government plans to present its next budget in rand, mandate the rand for tax assessments, and adopt it as the sole unit of account for the public and private sectors.

The coalition government also is examining ways to address public sector employee grievances, particularly concerning wages. Given the erosive nature of Zimbabwe's hyperinflationary environment, labor strikes by doctors, teachers, nurses, and government employees have been a regular occurrence over recent years. As a first step, the government is conducting an audit of public sector payrolls to remove ghost workers. While this will free up budgetary resources to increase salary payments for real workers, additional measures will be required to improve morale and productivity.

The government also plans to implement a series of reforms to improve the business environment with the aim of attracting foreign capital. Key components will include the provision of adequate property rights and contract sanctity assurances, which were systematically undermined by the Mugabe regime. There is widespread agreement that foreign capital and donor assistance will be critical to turning around the Zimbabwean economy.

\section{Current Debt Dynamics}

General Overview: According to the IMF, Zimbabwe is already in “debt distress”. As of end-2008, Zimbabwe's public and publicly guaranteed (PPG) external debt stood at \$5.1 billion - of which, nearly $\$ 4$ billion was in arrears. In relative terms, Zimbabwe's external debt is approximately 166 percent of the country's gross domestic product and 320 percent of annual export receipts. In 2008, debt service totaled roughly 270 percent of total government revenues. The sheer size, along with political turbulence and collapse of economic output, further explains the accumulation of external debt arrears (as noted above).

${ }^{13}$ IMF Country Report No. 09/139 
Absent debt relief, Zimbabwe's external debt ratios will remain highly unsustainable over the medium- to long-term. Figure 3 below compares Zimbabwe's existing debt ratios to those deemed sustainable for "poor performing" countries under the World Bank/IMF Debt Sustainability Framework (DSF). ${ }^{14}$

\section{Figure 3 - External Debt Ratios versus Respective World Bank/IMF Debt Sustainability Framework Thresholds}

\begin{tabular}{lccc} 
& Debt-to-GDP & Debt-to-Exports & Debt Service-to-Exports \\
\hline Zimbabwe & $166 \%$ & $320 \%$ & $22 \%$ \\
DSF Thresholds & $30 \%$ & $100 \%$ & $15 \%$ \\
\hline Differential & $136 \%$ & $220 \%$ & $7 \%$
\end{tabular}

Paris Club: As of September 2008, Paris Club creditors had nearly $\$ 2.1$ billion in outstanding claims on Zimbabwe. Of this, $\$ 1.2$ billion was for development assistance loans and the remainder for non-concessional loans. United States government exposure to Zimbabwe totals roughly \$205 million, which includes accumulated interest arrears. Other Paris Club creditors currently are unwilling to publicly share their exposure figures. However, it is commonly known that the largest Paris Club creditors are Germany, France, United Kingdom, Japan, and the United States (in descending order).

In light of the non-transparent reporting, we have examined publicly available information on development assistance loans extended by OECD-DAC member countries since 1980 (see Appendix III). Germany has provided the largest amount of development loans by far (\$338 million) - followed by Japan (\$167 million), the European Commission (\$140 million), France (\$136 million), Italy (\$126 million), United Kingdom (\$94 million), Finland (\$82 million), and the United States (\$67 million). Canada, which assumes the G-8 Presidency this fall, provided only \$24 million in development loans. These figures do not reflect loan repayments and the accumulation of interest arrears - nor do they include non-concessional loans such as export credits.

Non-Traditional Creditors: Given the cessation of traditional donor funding, such as the IFIs and Paris Club member countries, non-traditional creditors have played an increasingly important role in recent years. Press reports and anecdotal evidence suggests that China, Malaysia, and some Middle Eastern countries (e.g., Iran) provided several billions of dollars in loans since 2000. Some of these loans likely were collateralized with mineral deposits (e.g., gold, platinum) and/or export receipts. The new Zimbabwean government will need to conduct a careful and thorough audit of these external debt commitments in the coming months. The result could be a potentially large

\footnotetext{
${ }^{14}$ The World Bank/IMF Debt Sustainability Framework determines "sustainable” debt levels based upon the performance level of recipient governments. The underlying premise is that poorly governed countries are more likely to become debt-distressed at lower external indebtedness levels. Performance levels are based upon the World Bank's and African Development Bank’s Country Policy and Institutional Assessments (CPIA), which evaluate countries according to 16 policy categories. A "poor performing" country is defined as having a CPIA score of less than 3.25 (out of 6). In operational terms, IDA and AfDF compare these debt distress thresholds against current and projected debt ratios to determine risk classifications. In turn, these classifications determine whether a country should receive grants, loans, or a combination of the two.
} 
upward adjustment of Zimbabwe’s external debt stock above the current \$5.1 billion level and the associated indebtedness indicators.

In June 2009, the Zimbabwean government announced a \$950 million credit line from China. However, the terms and projected use are unclear at this point. Large Chinese credit lines to other African countries, such as Nigeria and Angola, have not been utilized extensively. Nonetheless, any usage would further increase Zimbabwe's external indebtedness levels and complicate the arrears clearance and debt relief process.

Domestic Debt: Zimbabwe's domestic debt situation is less acute. The Reserve Bank of Zimbabwe fully repaid local currency-denominated debt in late January 2009.

Hyperinflation, which reached 500 billion percent in September 2008, made the value of these domestic debt obligations worthless. Hence, the Reserve Bank was able to clear these obligations with relative ease. The remainder of domestic debt obligations is denominated in foreign-currency. As of December 2008, these obligations totaled nearly $\$ 460$ million. $^{15}$

Commercial Debt Exposure: Publicly available information on Zimbabwe's commercial debt exposure is limited. Similar to non-traditional creditors, the Zimbabwean government will need to conduct a thorough audit of commercial creditor claims and repayment status. Commercial credit has been limited in recent years due to the worsening economic crisis; however, historical claims potentially may be significant. One institution that continued to facilitate credit is the Cairo-based Africa Export-Import Bank, which has one of its two regional headquarters offices in Harare. ${ }^{16}$ In 2006/2007, Afrexim Bank financed five transactions for the Zimbabwean government totaling \$115 million in trade credit. Third-party institutions, such as BNP Paribas, provided an additional \$115 million for these transactions. Of the total, \$180 million went directly to the Reserve Bank of Zimbabwe. ${ }^{17}$ Similar to non-traditional creditors, the new Zimbabwean government will need to conduct a careful and thorough audit of commercial debt commitments over the coming months. Moreover, the government will need to examine whether commercial creditors have pursued litigation in response to non-payment. This has been a serious problem in several HIPCs, such as Liberia and the Republic of Congo (see Appendix IV). In Liberia, commercial creditor litigation awards totaled $\$ 357$ million, or 49 percent of its GDP.

\section{Arrears Clearance Process and IFI Reengagement}

The arrears clearance process is complicated, lengthy, and based on a precise sequencing of incremental actions. While each respective institution or body (World Bank, African Development Bank, IMF, and Paris Club) has its own specific policies and requirements, inter-institutional coordination plays a critical role. We lay out each organization's arrears clearance process and policies below - while noting the interlinkages among them. Moreover, strong political support from IFI shareholders and (mostly the same)

\footnotetext{
${ }^{15}$ IMF Country Report No. 09/139, p28.

16 The other is in Abuja, Nigeria.

${ }^{17}$ Africa Export-Import Bank, 2007 Annual Report
} 
bilateral donors is critical to advancing the processes expeditiously. Given this, the Zimbabwean government needs to cultivate close relationships with the most influential shareholders and creditors, address any related concerns, and establish a clear track record of implementing sound policies going forward.

World Bank: IDA utilizes two general approaches for arrears clearance operations - of which, both require formal approval by the World Bank Board of Directors. First, IDA can utilize a recipient country's regular allocation to clear World Bank Group arrears. ${ }^{18}$ Second, the World Bank can provide an "exceptional arrears clearance grant”. This entails the provision of a bridge loan by a donor, which in turn would be repaid with the proceeds of the exceptional IDA grant. Zimbabwe's regular allocation would only cover a small portion of existing IBRD and IDA arrears (roughly 15 percent). Therefore, it will require an exceptional arrears clearance grant.

Eligibility Criteria: To qualify for exceptional arrears clearance support, recipient countries must meet IDA's basic income and creditworthiness criteria (outlined in greater detail in Section VII). In addition, the World Bank will work closely with the Zimbabwean government to establish a track record of performance on macroeconomic and development-related reform measures. In this context, Zimbabwe will need to meet three key additional conditions: (1) commitment to implement a medium-term reform program endorsed by the World Bank; (2) performance under an IMF program; and (3) an agreed financing plan to clear other IFI arrears simultaneously. ${ }^{19}$ Lastly, Zimbabwe must become eligible for the HIPC Initiative prior to the arrears clearance operation (see Section VI below).

Available Funding: Under the $15^{\text {th }}$ IDA Replenishment, shareholders agreed to earmark $\$ 1.1$ billion to finance arrears clearance operations for Zimbabwe, Cote d'Ivoire, Liberia, Sudan, and Togo. Moreover, the Replenishment Agreement stipulates that any unused arrears clearance resources would carry over to the IDA-16 period (2011-2014). In the event of financing shortfalls, additional resources would be mobilized through the $16^{\text {th }}$ IDA Replenishment. ${ }^{20}$ Therefore, the World Bank should have adequate resources to clear Zimbabwe's arrears to IDA and the IBRD.

Repayment Capacity and Financing Needs: IDA staff will conduct an assessment of Zimbabwe's repayment capacity to determine the appropriate volume and concessionality of exceptional IDA resources required to clear all outstanding World Bank Group arrears. This assessment will be carried out in close cooperation with the IMF and African Development Bank. In general, it will address three issues: (1) domestically available resources $^{21}$; (2) debt sustainability concerns ${ }^{22}$; and (3) financing gap projections. Given

\footnotetext{
${ }^{18}$ While non-accrual status (i.e., existence of payment arrears) disqualifies countries from utilizing their regular allocation for development programs, they may utilize it for arrears clearance operations.

${ }^{19}$ In practice, the World Bank can agree to a sequential arrears clearance approach on a case-by-case basis. This approach requires mutual agreement among all relevant IFIs (IMF and AfDB).

${ }^{20}$ World Bank (2008), Additions to IDA Resources: Fifteenth Replenishment, p40.

${ }^{21}$ Under the domestic resource pillar, IDA will consider: (i) international reserves relative to imports; (ii) any limitations to utilizing reserves to repay external arrears; (iii) fiscal account projections; (iv) the level
} 
Zimbabwe's fragile fiscal and macroeconomic state, the World Bank likely will not require the government to contribute substantial (or possibly any) domestic resources towards the arrears clearance operation.

African Development Bank: The AfDB's Fragile States Facility (FSF) currently is the institution's central vehicle for arrears clearance and reengagement with countries emerging from conflict or crisis. The FSF operates as an autonomous trust fund within the AfDB Group and receives earmarked funding through AfDF replenishments (i.e., donor member countries). It also can receive resources out of the AfDB's net income or surplus account. The FSF has three support pillars: (1) arrears clearance; (2) supplementary financing; and (3) capability building support.

Arrears Clearance Pillar: The FSF's Arrears Clearance Pillar provides partial funding for clearing AfDB Group arrears, which helps to facilitate reengagement and normalization with the Bank. As a general rule, the recipient country must provide up to one-third of the financial resources required to clear all outstanding arrears. Donors may provide contributions on behalf of the recipient country to meet this requirement. The FSF provides the remaining two-thirds of the required financing. However, the FSF has flexibility to adjust the burden-sharing arrangement to reflect country repayment capacity and extenuating circumstances.

Eligibility Criteria: There are several staged criteria that determine country eligibility for FSF support. To access the supplementary financing window, a country must: (1) meet conditions for consolidating peace and security; (2) have experienced significant economic damage as a result of conflict or crisis; (3) improve macroeconomic conditions and debt management practices; (4) pursue sound financial management and business climate policies; and (5) increase transparency and accountability of financial management systems. Additional eligibility criteria apply to arrears clearance resources, including: (1) respect for the AfDB's preferred creditor status ${ }^{23}$; and (2) eligibility for HIPC debt relief. The AfDB Board of Directors must formally approve country eligibility for FSF support.

Available Funding: As of May 2009, the FSF had no available resources to finance new arrears clearance operations. Under the $11^{\text {th }}$ AfDF Replenishment Agreement, member countries authorized the transfer of UA 420 million (roughly $\$ 650$ million). Also, the FSF gained access to any remaining balances within the AfDB's Post-Conflict Countries Facility (previously UA 165 million, or roughly $\$ 250$ million). However, all approved funding was allocated to other countries emerging from crisis, such as Liberia. Therefore, additional resources must be mobilized for Zimbabwe to clear its AfDB arrears. The most viable option is an earmark within the $12^{\text {th }}$ AfDF Replenishment,

of domestic capital market development to absorb a new issuance of government bonds; and (v) government net deposits in the banking system and Reserve Bank.

${ }^{22}$ The World Bank and IMF will prepare a forward-looking debt sustainability analysis to determine future financing terms after arrears have been cleared.

${ }^{23}$ This includes servicing new maturities on all outstanding AfDB Group loans or at least repayments on the relative level provided to other IFIs. If needed, the AfDB permits bilateral donors to provide these repayments on the country's behalf. 
which member countries will begin negotiating in fall 2009. Alternatively, the AfDB could hold a special donor conference to solicit FSF contributions.

IMF: As of April 2009, Zimbabwe's arrears to the PRGF Trust Fund totaled \$134 million, or roughly 25 percent of its IMF quota. There are several options for clearing these IMF arrears. First, the IMF announced its plan to disburse $\$ 250$ billion in new Special Drawing Rights (SDRs) to member countries in an attempt to boost liquidity and international reserves in response to the global economic crisis. The IMF will allocate SDR disbursements based upon member countries' proportion of IMF quotas (i.e., subscriptions). ${ }^{24}$ Under this plan, Zimbabwe will receive SDR 262 million (\$408 million). Therefore, Zimbabwe could utilize a portion of these proceeds to clear all remaining PRGF Trust Fund arrears.

Alternatively, Zimbabwe could pursue the more traditional arrears clearance route. This entails a third-party bridge loan, which is paid off simultaneously through a new PRGF loan to Zimbabwe. ${ }^{25}$ This approach involves several related steps. First, the IMF Board must approve Zimbabwe's eligibility to use PRGF resources. Given Zimbabwe's lack of policy track record, it likely will need to implement an IMF Staff-Monitored Program before advancing to the PRGF program. Third, the IMF requires the clearance of official bilateral arrears (either paid off or rescheduled) and that other IFI arrears (World Bank, AfDB) are cleared or programmed to be cleared. Lastly, the IMF will require credible assurances that Zimbabwe will be able to repay the new PRGF loan. This step will present a significant hurdle given Zimbabwe's acute fiscal situation and credible rumors that export receipts have been pledged as loan collateral (as noted in Section IV). This may require a donor country providing a guarantee to meet any repayment deficits on the Zimbabwean government's behalf.

Paris Club: The Paris Club is an informal, consensus-based group of creditor countries that are guided by several principles, including:

- Comparability of Treatment: The recipient country cannot provide more favorable debt treatment terms to non-Paris Club creditors. Put differently, non-Paris Club creditors (other bilateral creditors, commercial banks, bondholders, etc) are expected to provide roughly the same (or better) levels of debt service or stock relief.

- Conditionality: The Paris Club only negotiates debt restructurings with debtor countries that clearly demonstrate: (a) need for debt relief; and (b) a reform track

\footnotetext{
${ }^{24}$ The IMF will distribute SDR allocations totaling roughly 74.13 percent of each member countries' quota.

${ }^{25}$ If Zimbabwe elects to utilize GRA resources to clear arrears, the IMF Board first must lift Zimbabwe's suspension of voting rights and reverse its ineligibility to utilize the IMF's general resources. This would require a 70 percent voting majority of the Board. Continued restrictions following Zimbabwe's clearance of GRA arrears has been justified by Zimbabwe's use of exchange rate restrictions and multiple currency practices as well as its lack of reporting on international reserves. While these justifications largely were institutional cover for a politically-based decision, Zimbabwe will need to address them to ensure the expeditious removal of IMF sanctions.
} 
record under an IMF program. ${ }^{26}$ In the case of a long-term debt service (flow) treatment, the Paris Club agreement is divided into multiple phases. The amounts falling due during the first phase are treated immediately upon the agreement's entry into force. Subsequent phases are implemented as agreed conditions are met ${ }^{27}$, such as non-accumulation of new arrears and satisfactory IMF program reviews.

- Case-by-Case Approach: The Paris Club makes decisions on a case-by-case basis in order to tailor actions to each debtor country's specific situation. The level of the debt treatment is based on the financing gap identified through the IMF program.

To clear Zimbabwe's arrears, the Paris Club likely will apply Naples Terms to the rescheduling. This would entail: (1) consolidating existing arrears; (2) rescheduling new payments over a set period of time (e.g., three years); and (3) applying a 67 percent reduction of payment obligations in net present value terms. Given the Zimbabwean government's fragile financial situation, careful consideration will be required to prevent any lapses in future repayments. This is especially important as any subsequent Paris Club agreements, such as HIPC debt relief (outlined in greater detail below), would require that Zimbabwe stay current on these newly rescheduled repayments. Due to IFIs' preferred creditor status and the requirement for a formal IMF program, Paris Club arrears would be cleared after the IMF and likely the World Bank and African Development Bank. ${ }^{28}$

As noted briefly above, new and/or preexisting loans by non-traditional creditors, such as China, may complicate the Paris Club rescheduling process. The comparable treatment principle will require that Zimbabwe treat Paris Club creditors in a similar fashion as other creditors. For example, if the Zimbabwean government maintains debt repayments to the Chinese government, then the Paris Club may be unwilling to reschedule and reduce its own claims.

\section{Debt Relief Process}

Heavily Indebted Poor Countries Initiative (HIPC): Since the mid-1990s, the HIPC Initiative has functioned as the guiding framework for providing comprehensive debt relief to low-income countries. Originally launched by the World Bank and IMF in 1996, it was later enhanced in 1999 to provide deeper and faster debt relief to a broader set of countries. The HIPC Initiative utilizes debt relief to lower countries' external debt situation to levels considered sustainable. Under the Original HIPC Initiative (1996-

\footnotetext{
${ }^{26}$ In practice, the recipient country must have a current IMF program, such as a Stand-By, Extended Fund Facility, Poverty Reduction and Growth Facility, or perhaps a non-borrowing program (Policy Support Instrument).

${ }^{27}$ All relevant conditions are included in the Agreed Minutes circulated by the Paris Club Secretariat. The Agreed Minutes are not a legally-binding agreement between the debtor and each Paris Club creditor. They constitute a recommendation to the Paris Club creditor governments and the recipient country to conclude bilateral agreements implementing the provisions of the Agreed Minutes terms.

${ }^{28}$ There are no firm rules stipulating that the World Bank and African Development Bank must clear their arrears prior to a Paris Club rescheduling. However, this is the typical sequencing.
} 
1999), the target was an external debt-to-exports ratio of 200 percent. The Enhanced HIPC Initiative (1999-current) further reduced the target external debt ratio to 150 percent of exports.

Eligibility Requirements: Countries must meet a number of criteria to become eligible for the HIPC Initiative. First, they must be classified as an "IDA-only" country. This means that the country is not eligible to receive market-based loans from the IBRD. Similarly, the country must only be eligible to receive loans from the IMF's Poverty Reduction and Growth Facility (PRGF) and not from the IMF's General Resource Account (GRA). ${ }^{29}$ Second, the country must face an unsustainable debt burden after the full application of traditional Paris Club mechanisms, such as Naples terms. ${ }^{30}$ As noted above, the country must have a debt-to-export ratio above 150 percent or a debt-togovernment revenue ratio above 250 percent. ${ }^{31}$ Only external debt incurred by end-2004 is eligible for HIPC Initiative consideration and debt relief. ${ }^{32}$ Third, the country must begin to establish a track record of reform. Typically, this step requires an IMF upper credit tranche program (e.g., PRGF program). However, exceptions have been made to utilize a staff-monitored program to establish a performance track record. Lastly, it must begin developing a Poverty Reduction Strategy Paper (PRSP), either on an interim- or formal-basis. PRSPs outline the relevant macroeconomic, structural and social programs that will promote growth and reduce poverty. They also estimate the associated external financing required for effective implementation. Currently, 40 countries are eligible for the HIPC Initiative; Zimbabwe is not among them. ${ }^{33}$

In 2004, World Bank and IMF shareholders closed the list of HIPC eligible countries. At the time, a number of additional countries were "grandfathered" into the Initiative, including: Afghanistan, Eritrea, Haiti, and the Kyrgyz Republic. Zimbabwe was not grandfathered for eligibility since it was classified as an IDA-blend country. Thus, it did not meet the HIPC Initiative's income and creditworthiness criterion. As a result, the World Bank and IMF Board of Directors will need to formally decide to re-open HIPC eligibility for Zimbabwe. Section VII examines how Zimbabwe currently stacks up on HIPC eligibility requirements.

Interim Debt Relief (HIPC Decision Point): Once becoming HIPC-eligible, a country must meet a series of performance criteria before receiving interim debt service relief.

\footnotetext{
${ }^{29}$ As noted previously, PRGF lending is limited to low-income countries and GRA assistance is tailored for middle-income countries.

30 "Naples Terms" provide debt stock reduction of up to 67 percent from Paris Club creditors and rescheduling terms for remaining debt.

${ }^{31}$ This second ratio is designed to capture countries where the fiscal burden of external debt is particularly acute. Several countries, such as Guyana, have used this so-called fiscal ratio to secure HIPC eligibility.

${ }^{32}$ This also means that end-2004 data is utilized to determine whether the country's external indebtedness ratios are unsustainable.

${ }^{33}$ Heavily Indebted Poor Countries (HIPCs) include: Afghanistan, Benin, Bolivia, Burkina Faso, Burundi, Cameroon, Central African Republic, Chad, Comoros, Republic of Congo, Cote d'Ivoire, Democratic Republic of Congo, Eritrea, Ethiopia, The Gambia, Ghana, Guinea, Guinea-Bissau, Guyana, Haiti, Honduras, Kyrgyz Republic, Liberia, Madagascar, Malawi, Mali, Mauritania, Mozambique, Nepal, Nicaragua, Niger, Rwanda, Sao Tome, Senegal, Sierra Leone, Somalia, Sudan, Tanzania, Togo, Uganda, and Zambia.
} 
First, the country must establish a track record of macroeconomic stability. Historically, the IMF and World Bank required sustained performance for 18 months. More recently, the time requirement has been reduced for many countries, sometimes as short as six months. Second, the country must finalize its Interim Poverty Reduction Strategy Paper. The Interim PRSP should incorporate input from a variety of relevant stakeholders, such as civil society and private businesses. Lastly, the country must clear any outstanding arrears to the World Bank, IMF, and African Development Bank. After this, World Bank and IMF staff will complete a formal loan-by-loan sustainability analysis to determine the country's indebtedness level and the amount of debt relief required to lower its external ratios to sustainable levels. These calculations will assume a standard Naples Terms treatment of Paris Club debt (67 percent NPV reduction) in determining the amount of IFI debt relief required. After which, the World Bank and IMF determine a 'common reduction factor' required by all creditors to bring Zimbabwe's external debt-to-exports ratio to 150 percent. Therefore, the Paris Club would be required to implement another debt treatment to implement the common reduction factor (on top of the Naples Terms treatment). The IFIs would only apply the common reduction factor to their existing loans under the HIPC Initiative. Lastly, the World Bank and IMF Executive Board of Directors must formally decide that the country should begin receiving interim debt service relief on a provisional basis (HIPC Decision Point status).

Irrevocable Debt Relief (HIPC Completion Point): To qualify for irrevocable debt relief, the country must meet additional performance criteria. First, it must continue to maintain macroeconomic stability under an IMF-supported program, such as a PRGF for one year. Second, the country must implement key structural and social reforms as agreed at the HIPC Decision Point. Lastly, the country must implement the Poverty Reduction Strategy Paper satisfactorily for one year. At this point, the World Bank and IMF Executive Board of Directors formally consider and approve irrevocable debt relief (HIPC Completion Point status). The HIPC framework also includes a "topping-up" provision by which additional debt relief can be applied in exceptional cases to offset exogenous factors that have fundamentally changed the country's economic circumstances, such as unexpected commodity price movements that severely impact export earnings.

Multilateral Debt Relief Initiative: In 2005, G-7 nations took the additional step of forcing the World Bank (IDA), African Development Bank (AfDF), and IMF to cancel 100 percent of their remaining debt claims outstanding on the world's poorest countries. ${ }^{34}$ Through the Multilateral Debt Relief Initiative (MDRI), HIPCs stand to receive up to \$60 billion in debt relief over time. To date, 24 countries have already seen the cancellation of over $\$ 30$ billion of debt obligations. ${ }^{35}$ MDRI eligibility is intertwined with the HIPC Initiative. Countries automatically receive 100 percent debt cancellation upon reaching

\footnotetext{
${ }^{34}$ Under MDRI, countries receive 100 percent debt relief on all remaining debt obligations prior to operable cutoff dates. The cutoff dates for eligible disbursed and outstanding debt are: (1) IDA December 31, 2003; (2) AfDF - December 31, 2004; and IMF - December 31, 2004. Debt that is contracted and/or disbursed after these cutoff dates are ineligible for MDRI relief.

${ }^{35}$ Source: Heavily Indebted Poor Countries (HIPC) Initiative and Multilateral Debt Relief Initiative (MDRI) - Status of Implementation, September 2008.
} 
HIPC Completion Point. In this manner, there are no additional eligibility requirements for MDRI debt relief assistance.

Non-Traditional Creditors: Under the HIPC Initiative, non-traditional creditors - such as China - are expected to provide comparable debt relief. These players account for roughly 13 percent of projected total HIPC debt relief costs. To date, the share of debt relief provided by non-traditional creditors has been low - roughly 40 percent of expected levels. ${ }^{36}$ Therefore, lack of progress has a direct impact on recipient countries. For completion point countries, China has provided roughly half of its expected share of debt relief. According to press reports, it signed a number of debt relief agreements with African countries over the last year. Nonetheless, Zimbabwe likely will face challenges in securing comprehensive debt relief assistance.

Commercial creditors: Debt restructuring or relief from commercial creditors is a process that depends on the respective exposure profiles. The so-called "London Club" has been the traditional forum for commercial debt reschedulings and relief treatments when banks are the main holders. It is an even more informal "club" of creditors formed on an ad hoc basis when requested by the debtor country. Although it sounds similar to the Paris Club, it does not have fixed members and the committees are dissolved once a deal is struck. In this sense, the London Club is less of an actual institution than an occasional meeting for all commercial sovereign debt holders to collectively negotiate restructuring with country officials. The term London Club may not even be used if the commercial debt is mostly held by private funds rather than banks. Like the official creditor groups, commercial creditors have typically sought comparability of treatment (no creditors can be treated differently from each other, including official creditors) and often use Paris Club terms as a benchmark. London Club negotiations have usually required 90-95 percent compliance to reach final agreement. The combination of potentially large (and often uncooperative) numbers of bondholders and the near-unanimity required to reach an agreed settlement means that commercial creditor negotiations can be time-consuming. ${ }^{37}$

IDA Debt Reduction Facility: The World Bank Executive Board established the Debt Reduction Facility (DRF) in 1989 to buy back debts owed to external, commercial creditors - at steep discounts - through grant funding to eligible governments. The Facility, which is managed by the Bank's Economic Policy and Debt Department, has played a significant role in reducing commercial debt exposure in low-income countries. To date, it has supported 22 buy-back operations in 21 IDA-only countries. Only one non-HIPC country (Albania) has received Facility assistance. ${ }^{38}$ These operations have removed roughly $\$ 4.5$ billion of commercial debt principal and more than $\$ 3.5$ billion of associated interest arrears and penalties. As a result, it has helped to reduce the risk of non-concessional creditors taking advantage of bilateral and multilateral debt relief (socalled "free riding"), which has the effect of improving debt repayment capacity. In this

\footnotetext{
${ }^{36}$ World Bank and IMF (2008). HIPC Initiative Progress Report

${ }^{37}$ London Club negotiations with Poland took more than a decade. More recently, Nigeria was able to conclude a buyback agreement with its commercial creditors in less than one year.

${ }^{38}$ World Bank (2004). Debt Reduction Facility for IDA-Only countries: Progress Report, Support to the HIPC Initiative, and Proposed Enhancements.
} 
manner, litigating creditors - often called "vulture funds" - derive the benefits from debt relief without having to pay anything for it.

Eligibility for Debt Reduction Facility support requires: (1) IDA-only status; (2) highlyindebted status; (3) satisfactory performance under a medium-term adjustment program (i.e., an IMF staff monitored program); and (4) satisfactory implementation of a debt management strategy. Only external commercial debt with a sovereign guarantee is eligible for Facility buy-back operations. ${ }^{39}$ To date, the average haircut for commercial creditors has been roughly 90 percent on Facility buy-back operations. In April 2009, Liberia secured a Facility-supported buy-back deal retiring $\$ 1.2$ billion in commercial claims, which included a 97 percent haircut for creditors.

\section{ZIMBABWE’S CASE FOR IDA RECLASSIFICATION}

IDA-Only Status: As noted briefly above, the World Bank classifies countries into two broad categories. Low-income countries have access to concessional loans and grants from IDA. Middle-income countries borrow from the IBRD - the World Bank's marketbased financing window. Eligibility for IDA's concessional assistance is based on two criteria - income and lack of commercial credit access. We examine how Zimbabwe matches up on each of these criteria.

Income Level: The current IDA income per capita threshold is \$1,095. In 2006, the World Bank estimated that Zimbabwe’s gross national income (GNI) per capita was roughly \$340. According to the IMF, Zimbabwe's GDP declined by an additional 10 percent in 2008 to approximately $\$ 3.18$ billion. ${ }^{40}$ With a static population size of 13.4 million, ${ }^{41}$ this would translate into a GDP per capita of $\$ 240$ in 2008 . Regardless of the exact figure, it is clear that Zimbabwe's current income levels are far below the IDA threshold by any relevant measure.

Figure 4 - Zimbabwe: GNI Per Capita versus Country Categories, 1980-2006

\begin{tabular}{crrrr} 
Year & Zimbabwe & Low-Income Avg & Middle-Income Avg & IDA Operational Cutoff \\
\hline 1980 & 930 & 398 & 757 & N/A \\
1985 & 740 & 287 & 758 & N/A \\
1990 & 860 & 309 & 972 & N/A \\
1995 & 600 & 293 & 1,231 & 905 \\
2000 & 450 & 320 & 1,392 & 895 \\
2001 & 530 & 324 & 1,401 & 885 \\
2002 & 780 & 329 & 1,421 & 865 \\
2003 & 760 & 358 & 1,560 & 875 \\
2004 & 560 & 410 & 1,829 & 865 \\
2005 & 340 & 462 & 2,146 & 895 \\
2006 & 340 & 517 & 2,479 & 965 \\
\hline
\end{tabular}

\footnotetext{
${ }^{39}$ Eligible debt includes medium- and long-term non-collateralized debts owed to external commercial creditors and short-term debt of similar nature that have been in long standing arrears.

${ }^{40}$ IMF (May 2009). Zimbabwe: 2009 Article IV Consultation - Staff Report.

${ }^{41}$ Zimbabwe's true population size is difficult to estimate given the significant exodus of people during the recent economic crisis and political repression. Many estimate that over 3 million Zimbabweans emigrated to South Africa, Botswana, Mozambique, Zambia, and other countries.
} 
Creditworthiness: Zimbabwe has virtually no access to private credit today and has not borrowed from the IBRD since 1994. As noted previously, Zimbabwe fell into payment arrears on its IBRD debt in 1999. In recent years, it has secured some external commercial credit based on export collateralization (e.g., platinum or gold deposits). As noted previously, credible reports suggest that China has provided substantial assetbacked loans to the Zimbabwean government. However, loans from entities with robust and credible financial risk management controls have evaporated in the last year or so. The conservative fiscal management policies, such as cash-based budgeting, recently implemented under Finance Minister Biti’s direction have further dissuaded nontraditional creditors from providing non-transparent loans to the Zimbabwean government. Currently, no reputable creditor would provide commercial loans to Zimbabwe given its extreme external debt burden.

For illustration purposes, below we compare Zimbabwe's current external debt ratios to those of other IDA-blend countries. For the debt-to-GDP ratio, only Grenada and Dominica exceed 50 percent. In both cases, the IMF has stressed the imperative of taking aggressive action to reduce external debt exposure. In contrast, Zimbabwe's debt-toGDP ratio is 166 percent, or roughly 137 percentage points higher than the average IDAblend country. Particularly striking is Zimbabwe's annual debt service-to-government revenues ratio of 270 percent.

\section{Figure 5 - External Indebtedness Ratios for Existing IDA-Blend Countries}

\begin{tabular}{|c|c|c|c|c|}
\hline \multirow[b]{2}{*}{ IDA-Blend Countries } & \multirow[b]{2}{*}{ IBRD Access } & \multicolumn{2}{|c|}{ Debt Stock Ratios } & \multirow{2}{*}{$\begin{array}{c}\text { Debt Service Ratios } \\
\text { Debt Service-to-Revenues }\end{array}$} \\
\hline & & Debt-to-GDP & Debt-to-Revenues & \\
\hline Armenia & Yes & $16 \%$ & $37 \%$ & $2 \%$ \\
\hline Azerbaijan & Yes & $19 \%$ & - & - \\
\hline Bolivia & No & $11 \%$ & $42 \%$ & $15 \%$ \\
\hline Bosnia-Herzegovina & Yes & $15 \%$ & & \\
\hline Dominica & Yes & $53 \%$ & $135 \%$ & $19 \%$ \\
\hline Georgia & Yes & $21 \%$ & - & - \\
\hline Grenada & Yes & $78 \%$ & - & - \\
\hline India & Yes & $19 \%$ & - & - \\
\hline Pakistan & Yes & $26 \%$ & - & - \\
\hline St. Lucia & Yes & $44 \%$ & $152 \%$ & $25 \%$ \\
\hline St. Vincent & Yes & $34 \%$ & $97 \%$ & $19 \%$ \\
\hline Uzbekistan & Yes & $11 \%$ & $29 \%$ & $2 \%$ \\
\hline Zimbabwe & No & $166 \%$ & $4378 \%$ & $270 \%$ \\
\hline Average (no Zimbabwe) & - & $29 \%$ & $82 \%$ & $13 \%$ \\
\hline Differential & - & $137 \%$ & $4296 \%$ & $257 \%$ \\
\hline
\end{tabular}

Source: IMF Article IV Country Reports

In addition, Zimbabwe appears to have as strong a case for reclassification based on historical precedent. The previous four African cases of "reverse graduation" to IDAonly status were Cote d'Ivoire in 1992, Cameroon and the Republic of the Congo in 
1994, and Nigeria in $2005 .^{42}$ In the earlier three cases, their status was changed soon after they dropped below the IDA income threshold (see Appendix VI). In Nigeria's case, this occurred only after a path to debt relief was already negotiated, but when the country's per capita income has plunged to less than half the threshold level. Although IDA classification is a decision taken by the World Bank staff, in practice they will look to the Board of Directors for guidance when to make such a change. In Zimbabwe's case, such a change is unlikely until the Board has given a clear signal that relations have normalized and debt relief is being actively pursued.

\section{CONCLUSION}

Zimbabwe is embarking on a long, complex, and difficult journey to rebuild its economy, which has been shattered by years of neglect and destructive government policies. If the final political hurdles are overcome, the new coalition government will be faced with making politically difficult decisions and to addressing conclusively the economic ghosts of the past. Clearing Zimbabwe's external debt arrears and securing comprehensive debt relief is a critical step in this process. By doing so, the government will remove a crippling burden on its budget, investment climate, and overall macroeconomic environment. More importantly to the success of the coalition government, it will unlock hundreds of millions of dollars in new external assistance for critical reconstruction programs that will improve the Zimbabwean people's quality of life. This paper provides a detailed overview of the arrears clearance and debt relief processes and hopefully will buttress the government's analytical foundation when it embarks on this important journey. With a strong dedicated team of experts - and support from relevant donor agencies - the Zimbabwean government will one day conclusively address its crushing debt burden and proceed with the rebuilding of a once vibrant and proud nation.

${ }^{42}$ See Todd Moss, Scott Standley, and Nancy Birdsall, "Double-Standards, Debt Treatment, and World Bank Country Classification: The Case of Nigeria,” CGD Working Paper Number 45, Center for Global development, Washington DC, November 2004. 


\section{World Bank: Historical Project List}

\begin{tabular}{|c|c|c|c|c|c|c|c|}
\hline PROJECT NAME & $\begin{array}{l}\text { APPROVAL } \\
\text { DATE } \\
\end{array}$ & $\begin{array}{l}\text { CLOSING } \\
\text { DATE }\end{array}$ & PROJECT COST & $\begin{array}{c}\text { IBRD } \\
\text { COMMITMENT }\end{array}$ & $\begin{array}{c}\text { IDA } \\
\text { COMMITMENT }\end{array}$ & $\begin{array}{c}\text { TOTAL WB } \\
\text { COMMITMENT }\end{array}$ & MAJOR SECTOR \\
\hline Manufacturing Rehabilitation Imports Program Project & 26-Mar-81 & 31-Mar-82 & 65 & 50 & 15 & 65 & Multi-Sector \\
\hline Transport Rehabilitation Imports Program Project & 19-Мay-81 & 30-Jun-86 & 42 & 42 & 0 & 42 & Infrastructure (Transportation) \\
\hline Small Farm Credit Project & 21-Sep-82 & 30-Jun-88 & 30.4 & 0 & 30.4 & 30.4 & Agriculture \\
\hline Petroleum Fuels Supply Technical Assistance Project & 28-Sep-82 & 30-Jun-86 & 1.2 & 0 & 1.2 & 1.2 & Infrastructure (Oil \& Gas) \\
\hline Power Project & 14-Dec-82 & 30-Jun-90 & 105.0 & 105.0 & 0.0 & 105.0 & Infrastructure (Power Sector) \\
\hline Manufacturing Export Promotion Project & 15-Feb-83 & 30-Jul-87 & 70.6 & 70.6 & 0.0 & 70.6 & Multi-Sector \\
\hline Rural Afforestation Project & 17-May-83 & 31-Mar-89 & 7.3 & 0.0 & 7.3 & 7.3 & Agriculture \\
\hline Highway Project (01) & 17-May-83 & 30-Jun-88 & 26.4 & 26.4 & 0.0 & 26.4 & Infrastructure (Transportation) \\
\hline National Agricultural Extension and Research Project (01) & 7-Jul-83 & 30-Sep-91 & 13.1 & 13.1 & 0.0 & 13.1 & Agriculture \\
\hline Railway Development Project & 2-Aug-83 & 30-Jun-90 & 121.3 & 40.0 & 0.0 & 40.0 & Infrastructure (Transportation) \\
\hline Urban Development Project & 19-Jun-84 & 30-Sep-93 & 43.0 & 43.0 & 0.0 & 43.0 & Infrastructure (Urban Development) \\
\hline Small Scale Enterprises Project (01) & 9-May-85 & 30-Jun-94 & 10.0 & 10.0 & 0.0 & 10.0 & SME Development \\
\hline Health Project & 22-Jul-86 & 30-Sep-93 & 10.0 & 10.0 & 0.0 & 10.0 & Health \\
\hline Power Project (02) & 12-Jan-88 & 30-Jun-94 & 44.0 & 44.0 & 0.0 & 44.0 & Infrastructure (Power Sector) \\
\hline Highway Project (02) & 10-May-88 & 30-Jun-95 & 32.7 & 32.7 & 0.0 & 32.7 & Infrastructure (Transportation) \\
\hline Agricultural Credit and Export Promotion Project & 18-May-89 & 31-Dec-97 & 36.3 & 36.3 & 0.0 & 36.3 & Agriculture \\
\hline Urban Project (02) & 1-Jun-89 & 31-Dec-99 & 580.0 & 80.0 & 0.0 & 80.0 & Infrastructure (Water) \\
\hline Forest Resources Management \& Development Project & 22-Mar-90 & 30-Jun-98 & 64.1 & 14.5 & 0.0 & 14.5 & Forestry \\
\hline Railways Project (02) & 4-Dec-90 & 30-Jun-99 & 263.2 & 38.6 & 0.0 & 38.6 & Infrastructure (Transportation) \\
\hline Family Health Project $(02)$ & 4-Jun-91 & 31-Dec-98 & 25.0 & 25.0 & 0.0 & 25.0 & Health \\
\hline Structural Adjustment Credit Project & 21-Jan-92 & 31-Dec-93 & 390.0 & 125.0 & 50.0 & 175.0 & Multi-Sector \\
\hline Emergency Drought Recovery and Mitigation Project & 24-Jun-92 & 31-Mar-95 & 151.1 & 0.0 & 150.0 & 150.0 & Infrastructure (Water) \\
\hline Sexually Transmitted Infections (STI) Prevention and Care & 17-Jun-93 & 31-Dec-00 & 64.5 & 0.0 & 64.5 & 64.5 & Health \\
\hline Structural Adjustment Credit (SAC) Project (02) & 29-Jun-93 & 31-Dec-97 & 125.0 & 0.0 & 125.0 & 125.0 & Multi-Sector \\
\hline Power Project (03) & 18-Jan-94 & 31-Dec-99 & 200.2 & 90.0 & 0.0 & 90.0 & Infrastructure (Power Sector) \\
\hline Enterprise Development & 25-Apr-96 & 31-Dec-02 & 106.0 & 0.0 & 70.0 & 70.0 & Infrastructure (Power Sector) \\
\hline Rural District Council Pilot Capital Development Project & 29-May-97 & 30-Jun-00 & 19.8 & 0.0 & 12.3 & 12.3 & Infrastructure (Water) \\
\hline Community Action Project & 19-May-98 & 31-Dec-03 & 60.0 & 0.0 & 60.0 & 60.0 & Health \\
\hline Agricultural Services and Management Project & 29-May-98 & 31-Jul-01 & 33.4 & 0.0 & 8.8 & 8.8 & Agriculture \\
\hline Park Rehabilitation and Conservation Project & 2-Jun-98 & 30-Sep-05 & 70.0 & 0.0 & 62.5 & 62.5 & Infrastructure (Water) \\
\hline Land Reform Support Project & 16-Sep-99 & 31-Dec-01 & 7.0 & 0.0 & 5.0 & 5.0 & Agriculture (Land Reform) \\
\hline TOTAL & & & $2,817.6$ & 896.2 & 662.0 & $\overline{1,558.2}$ & \\
\hline
\end{tabular}

\begin{tabular}{lrr}
\hline Sector Breakdown & WB Total & \multicolumn{1}{c}{ Percent } \\
\hline Infrastructure & 837.7 & $54 \%$ \\
Transportation & 179.7 & $12 \%$ \\
Oil \& Gas & 1.2 & $0 \%$ \\
Power Sector & 309.0 & $20 \%$ \\
Water & 304.8 & $20 \%$ \\
Multi-Sector & 435.6 & $28 \%$ \\
Agriculture & 100.9 & $6 \%$ \\
Health & 159.5 & $10 \%$ \\
SME Development & 10.0 & $1 \%$ \\
Forestry & 14.5 & $1 \%$ \\
\hline TOTAL & $\mathbf{1 5 5 8 . 2}$ & $\mathbf{1 0 0 \%}$
\end{tabular}

Source: World Bank country website (www.worldbank.org/zimbabwe) 
IMF: Historical Overview

\begin{tabular}{|c|c|c|c|c|c|c|c|c|}
\hline \multicolumn{2}{|c|}{ Time } & \multicolumn{3}{|l|}{ IMF Actions } & \multicolumn{4}{|c|}{$\begin{array}{l}\text { Actual Disbursement of Funds } \\
\end{array}$} \\
\hline Year & Date & Program and IMF Board Actions & $\begin{array}{l}\text { Commitment } \\
\text { (in SDRs) }\end{array}$ & $\begin{array}{l}\text { Program } \\
\text { Duration } \\
\end{array}$ & $\begin{array}{l}\text { General Resources Account } \\
\text { (in SDRs) }\end{array}$ & $\begin{array}{r}\text { PRGF-ESF T } \\
\text { (in S }\end{array}$ & $\begin{array}{l}\text { rust Account } \\
\text { ORs) }\end{array}$ & Total \\
\hline 1980 & & Initiated relationship with IMF & & & & & & \\
\hline 1981 & & & & & & & & \\
\hline 1982 & & & & & & & & \\
\hline 1983 & & & & & & & & \\
\hline 1984 & & & & & & & & \\
\hline 1985 & & & & & & & & \\
\hline 1986 & & & & & & & & \\
\hline 1987 & & & & & & & & \\
\hline 1988 & & & & & & & & \\
\hline 1989 & & & & & & & & \\
\hline 1990 & & IMF approves Enhanced Structural Adjustment Facility (ESAF) loan & & & & & & \\
\hline 1991 & & IMF initiates ESAF loan & $310,000,000$ & 4 years & & & & \\
\hline 1992 & & & & & $102,500,000$ & & $54,700,000$ & $157,200,000$ \\
\hline 1993 & & & & & $17,400,000$ & & $30,400,000$ & $47,800,000$ \\
\hline 1994 & & $\downarrow$ & & & $19,100,000$ & & $33,400,000$ & $52,500,000$ \\
\hline 1995 & & ESAF loan expires & $\downarrow$ & $\downarrow$ & $19,100,000$ & & $33,400,000$ & $52,500,000$ \\
\hline 1996 & & & & & $158,100,000$ & & $151,900,000$ & $310,000,000$ \\
\hline 1997 & & & & & & & & \\
\hline 1998 & 1-Jun & IMF approves Stand-By Credit Arrangement & $130,750,000$ & 13 months & $39,200,000$ & & 0 & $39,200,000$ \\
\hline 1999 & 2-Aug & IMF approves Stand-By Credit Arrangement & $141,360,000$ & 14 months & $24,740,000$ & & 0 & $24,740,000$ \\
\hline 2000 & $1-$ Oct & Stand-By Arrangement expires & & & $222,040,000$ & & $151,900,000$ & \\
\hline 2001 & & & Zimbabwe has & en in & Total IMF Dis & sbursements & & $373,940,000$ \\
\hline 2002 & 14-Jun & $\begin{array}{l}\text { IMF adopts Declaration of Noncooperation for Zimbabwe and suspends technical } \\
\text { assistance }\end{array}$ & $\begin{array}{l}\text { continuous arre } \\
\text { IMF since Febr }\end{array}$ & $\begin{array}{l}\text { s to the } \\
\text { ary } 2001\end{array}$ & & & & \\
\hline 2003 & 6-Jun & IMF suspends Zimbabwe's voting and related rights & and is the only & se of & & & & \\
\hline 2003 & 3-Dec & IMF initiates compulsory withdrawal procedures for Zimbabwe & protracted arrea & to the & & & & \\
\hline 2004 & 1-Oct & IMF closes Zimbabwe resident representative's office & PRGF-ESF Tru & , which & & & & \\
\hline 2005 & & & currently total $s$ & R 89 & & & & \\
\hline 2006 & & & million (about $\mathrm{C}$ & SD \$134 & & & & \\
\hline 2007 & & & million). & & & & & \\
\hline 2008 & & & & & & & & \\
\hline 2009 & 6-May & IMF Executive Board approves targeted technical assistance & & & & & & \\
\hline
\end{tabular}

Source: IMF press reports and country documents

Note: As of June 17, 2009, the exchange rate is SDR1=USD1.54 
Zimbabwe: Gross ODA Loan Disbursements, by OECD-DAC Creditor (Current USD millions)

\begin{tabular}{|c|c|c|c|c|c|c|c|c|c|c|c|c|c|c|c|c|c|c|c|c|c|c|c|c|}
\hline Donor & 1980 & 1981 & 1982 & 1983 & 1984 & 1985 & 1986 & 1987 & 1988 & 1989 & 1990 & 1991 & 1992 & 1993 & 1994 & 1995 & 1996 & 1997 & 1998 & 1999 & 2000 & 2001 & 2002 & Total \\
\hline Austria & & & 0.6 & & & & & & & & 8.8 & & & & & & & & & & & & & 9.4 \\
\hline Belgium & & 2.7 & & & & & & & & & & & & & & & & & & 1.0 & & & & 3.7 \\
\hline Canada & & 2.0 & 8.9 & & 2.8 & 5.1 & 4.7 & 0.6 & & & & & & & & & & & & & & & & 24.0 \\
\hline Denmark & & 5.2 & & 0.2 & 4.3 & 3.2 & 5.4 & 4.7 & 5.7 & 11.9 & 6.6 & 0.7 & 0.8 & 2.6 & 0.4 & 1.5 & 0.4 & 0.2 & 0.6 & 0.5 & 0.7 & 0.1 & & 55.5 \\
\hline EC & & & & 0.3 & 1.1 & & 0.7 & 1.0 & & & & & 0.1 & 19.9 & 25.2 & 45.6 & 23.5 & 11.3 & 5.6 & 6.4 & & & & 140.7 \\
\hline Finland & & & 2.2 & 1.2 & 1.0 & 4.3 & 3.6 & 6.0 & 2.7 & 9.3 & 10.1 & 11.8 & 9.2 & 8.4 & 0.1 & 6.5 & 4.8 & 0.5 & & & & & & 81.6 \\
\hline France & & & 7.9 & 8.0 & 5.7 & 4.6 & 3.6 & 12.9 & 9.3 & 9.3 & 15.7 & 15.7 & 7.5 & 4.5 & 9.1 & 10.3 & 7.3 & 0.4 & 0.3 & 1.8 & 1.5 & 0.5 & 0.0 & 136.0 \\
\hline Germany & 0.8 & 16.4 & 15.1 & 20.8 & 13.5 & 16.0 & 22.8 & 18.0 & 17.5 & 5.4 & 21.4 & 23.0 & 32.2 & 37.3 & & 24.3 & 16.0 & 21.4 & 11.1 & 3.3 & 0.8 & 0.2 & 0.3 & 337.5 \\
\hline Italy & & & & & 13.4 & 3.6 & 0.2 & 18.8 & 6.1 & 7.1 & 3.5 & 7.6 & 12.1 & 11.9 & 11.9 & 8.0 & 16.6 & 5.2 & & & & & & 125.8 \\
\hline Japan & & & & 7.6 & 9.3 & 2.6 & 1.4 & 6.3 & 0.2 & 1.1 & 7.8 & 12.9 & 9.2 & 8.0 & 3.3 & 1.7 & 4.5 & 2.4 & 1.9 & 33.5 & 21.8 & 16.3 & 14.8 & 166.5 \\
\hline Luxembourg & & & & & & & & & & & & & & & & & & & & & & & & 0.0 \\
\hline Netherlands & & 4.0 & 7.2 & 4.2 & 7.5 & 8.1 & 4.2 & 5.1 & 3.0 & 1.7 & 1.6 & 0.0 & 11.2 & 1.6 & & & & & & & & & & 59.4 \\
\hline Spain & & & & & & & & & & & & & 6.8 & 6.0 & & & & & 6.3 & 3.1 & 0.9 & & & 23.0 \\
\hline Switzerland & & & 1.1 & 1.9 & 1.1 & 1.9 & 2.0 & 0.2 & & 0.3 & 0.1 & & & & & & & & 0.0 & 0.1 & & & & 8.6 \\
\hline United Kingdom & & 13.0 & 12.5 & 6.6 & 3.9 & 2.8 & 0.6 & 3.7 & 2.5 & 0.6 & 0.1 & 1.0 & 0.5 & 2.4 & & 2.0 & 8.5 & 5.7 & 16.2 & 7.4 & 5.0 & 0.5 & -1.8 & 93.6 \\
\hline United States & & & & & 3.0 & 9.0 & & & & & & & 40.0 & 5.0 & & & & & 9.9 & & & & & 66.9 \\
\hline Total & 0.8 & 43.2 & 55.4 & 50.8 & 66.6 & 61.0 & 49.2 & 77.1 & 47.0 & 46.6 & 75.7 & 72.5 & 129.5 & 107.4 & 50.0 & 99.7 & 81.6 & 47.1 & 51.9 & 57.0 & 30.8 & 17.7 & 13.4 & $1,332.0$ \\
\hline
\end{tabular}

Source: OECD-DAC

Note - OECD-DAC member countries have not provided ODA loan disbursements to Zimbabwe since 2002 


\section{Appendix IV}

HIPCs: Commercial Creditor Litigation (as of end-2007)

\begin{tabular}{|c|c|c|c|c|c|}
\hline \multirow{2}{*}{ Country } & \multirow{2}{*}{$\begin{array}{c}\text { Litigating Creditors } \\
\text { (number) }\end{array}$} & \multicolumn{2}{|c|}{ Claims } & \multicolumn{2}{|c|}{ Court Awards } \\
\hline & & (in USD millions) & (\% of GDP) & (in USD millions) & (\% of GDP) \\
\hline Afghanistan & 0 & 0 & 0 & 0 & 0 \\
\hline Benin & 0 & 0 & 0 & 0 & 0 \\
\hline Bolivia & 0 & 0 & 0 & 0 & 0 \\
\hline Burkina Faso & 0 & 0 & 0 & 0 & 0 \\
\hline Burundi & 0 & 0 & 0 & 0 & 0 \\
\hline Cameroon & 4 & 158 & 0.8 & 51 & 0.2 \\
\hline Central African Republic & 0 & 0 & 0 & 0 & 0 \\
\hline Chad & - & - & - & - & - \\
\hline Comoros & - & - & - & - & - \\
\hline Congo, Democratic Republic of & 1 & 100 & 1.0 & 100 & 1.0 \\
\hline Congo, Republic of & 8 & 575 & 7.5 & 443 & 5.8 \\
\hline Cote d'Ivoire & - & - & - & - & - \\
\hline Eritrea & - & - & - & - & - \\
\hline Ethiopia & 2 & 187 & 1.0 & - & - \\
\hline Gambia, the & - & - & - & - & - \\
\hline Ghana & 0 & 0 & 0 & 0 & 0 \\
\hline Guinea & - & - & - & - & - \\
\hline Guinea-Bissau & 0 & 0 & 0 & 0 & 0 \\
\hline Guyana & 3 & 46 & 4.5 & - & - \\
\hline Haiti & 0 & 0 & 0 & 0 & 0 \\
\hline Honduras & 1 & 1 & 0 & - & - \\
\hline Kyrgyz Republic & 0 & 0 & 0 & 0 & 0 \\
\hline Liberia & 10 & 130 & 17.8 & 357 & 49.0 \\
\hline Madagascar & - & - & - & - & - \\
\hline Malawi & 0 & 0 & 0 & 0 & 0 \\
\hline Mali & - & - & - & - & - \\
\hline Mauritania & 0 & 0 & 0 & 0 & 0 \\
\hline Mozambique & 0 & 0 & 0 & 0 & 0 \\
\hline Nepal & - & - & - & - & - \\
\hline Nicaragua & 5 & 9 & 0.2 & 0 & 0 \\
\hline Niger & 0 & 0 & 0 & 0 & 0 \\
\hline Rwanda & 0 & 0 & 0 & 0 & 0 \\
\hline Sao Tome \& Principe & 0 & 0 & 0 & 0 & 0 \\
\hline Senegal & 0 & 0 & 0 & 0 & 0 \\
\hline Sierra Leone & 5 & 29 & 1.7 & 25 & 1.5 \\
\hline Sudan & 3 & 151 & 0.3 & 146 & 0.3 \\
\hline Tanzania & 0 & 0 & 0 & 0 & 0 \\
\hline Togo & - & - & - & - & - \\
\hline Uganda & 6 & 36 & 0.3 & 30 & 0.3 \\
\hline Zambia & 2 & 55 & 0.5 & 16 & 0.1 \\
\hline TOTAL & 50 & 1,477 & & 1,168 & \\
\hline
\end{tabular}

Source: World Bank and IMF (September 2008), Heavily Indebted Poor Countries (HIPC) and Multilateral Debt Relief Initiative (MDRI) - Status of Implementation, p27 


\section{Zimbabwe: IFI Arrears Clearance and Debt Relief Process}

Preparatory Work \& Analysis

\begin{tabular}{|l|l|}
\hline $\begin{array}{l}\text { (1) Secure debt relief champion } \\
\text { (2) Compile all existing debt obligations } \\
\text { (3) Audit debt claims for accuracy and status } \\
\text { (4) Complete IMF Article IV review (updated } \\
\text { country data and analysis) } \\
\text { (5) Secure IFI technical assistance }\end{array}$ \\
Regular IDA and AfDF \\
loans/grants resume
\end{tabular}

HIPC Decision Point Eligibility

(1) Complete Interim PRSP

(2) Satisfactory IMF Agreement performance

(3) Paris Club Agreement

(4) IFI Board approval for interim HIPC Relief

(conditional debt service relief)

(5) Initiate IDA Debt Reduction Facility

negotiations

\section{$\downarrow$}

HIPC Completion Point Eligibility

(1) Satisfactory IMF Agreement performance

(2) PRSP implementation for one-year

(3) Achieve IMF/WB structural reform triggers

(4) Final Paris Club Agreement

(5) IFI Board Approval for Completion Point

(irrevocable debt stock relief reducing NPV

debt/export ratio to $150 \%$ ) 


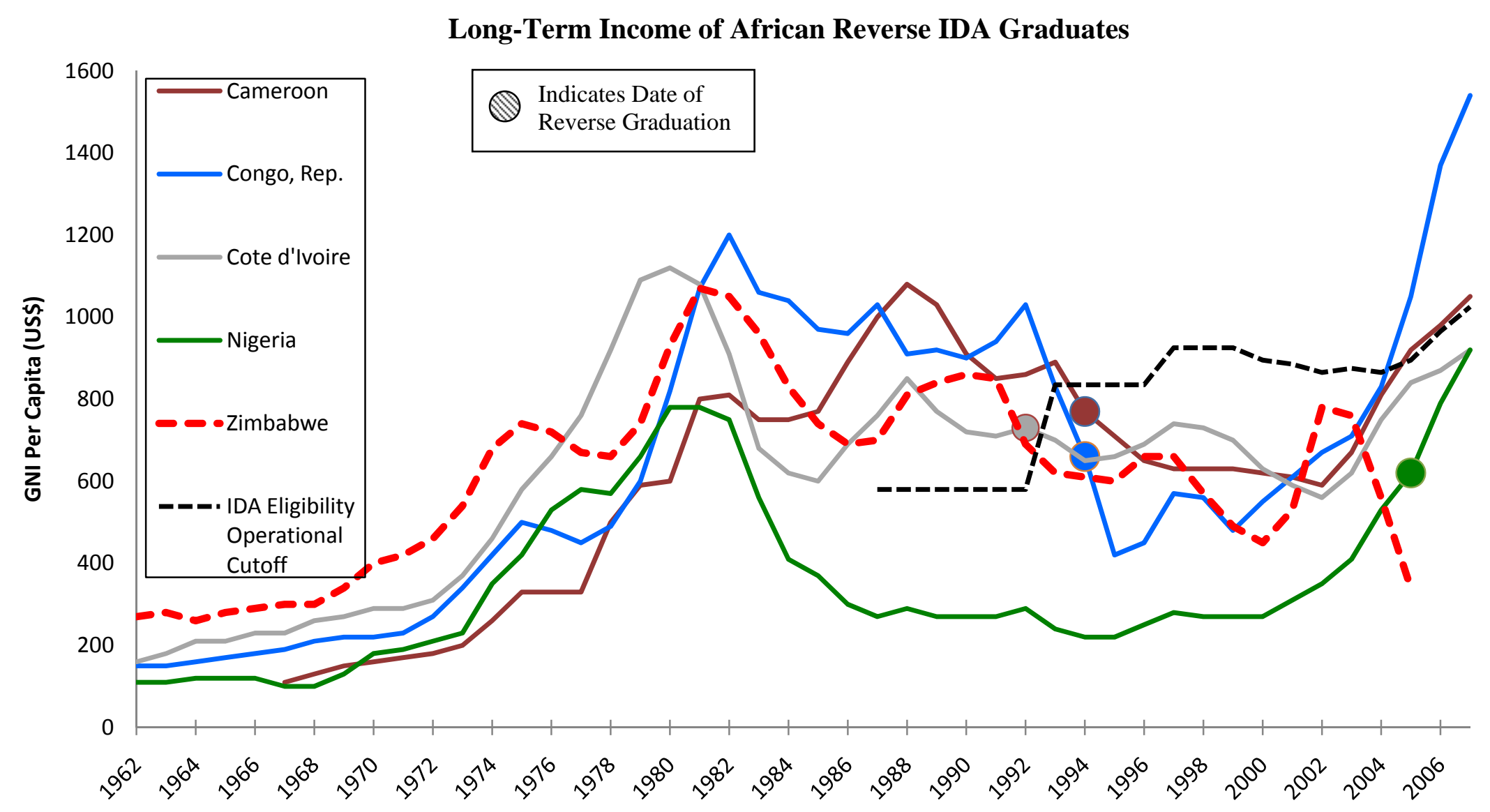

Source: GNI Per Capita data from 2008 World Development Indicators; IDA Eligibility Operational Cutoff data from World Bank, Asian Development Bank, United Nations, and International Monetary Fund publications 
Appendix VII

\section{Zimbabwe Democracy and Economic Recovery Act (ZDERA)}

In 2001, the U.S. Congress passed the Zimbabwe Democracy and Economic Recovery Act (ZDERA), which provided a symbolic gesture of support for 'the people of Zimbabwe in their struggle to effect peaceful and democratic change, achieve broad-based and equitable economic growth, and restore the rule of law.' In punitive terms, ZDERA prohibits the provision of U.S. development assistance until the President of the United States certifies that Zimbabwe has met a number of conditions. ${ }^{43}$ The only exemptions include assistance for humanitarian purposes or governance reforms. In addition, ZDERA requires that the U.S. Executive Director ${ }^{44}$ at each International Financial Institution must oppose and vote against any new loan, credit, guarantee, or the provision of IFI debt relief.

In practice, ZDERA has had no discernible impact on U.S. or IFI assistance programs. First, the World Bank, African Development Bank, and IMF each halted their assistance programs in 2000 on their own after the Zimbabwean government went into payment arrears. In other words, the Zimbabwean government effectively imposed financial sanctions on itself due to its lack of payment compliance. Even if Zimbabwe remained eligible for new assistance, it is highly unlikely that the U.S. Treasury Department alone would have been able to prevent it. Given its relatively small voting share, ${ }^{45}$ the U.S. would need to build large shareholder coalitions to block any new IFI assistance. This has proven very difficult in the past. For example, the U.S. Congress has imposed similar IFI voting directives in the case of Iran. Despite this, the World Bank approved projects totaling nearly \$900 million for Iran between 2003 and 2005. With respect to ZDERA's impact on bilateral programs, the U.S. Government already had made a decision to halt development assistance programs - with the exception of humanitarian aid - following the un-democratic and repressive elections in 2000. In this manner, the Congress merely codified existing U.S. foreign policy and did not have an incremental impact on the ground.

While ZDERA has not been the driver of policy decisions, it will nonetheless play an important role in the context of Zimbabwe's efforts to clear IFI arrears and secure new assistance, including debt relief. Now that the Obama Administration supports reengaging the Zimbabwean government, ZDERA's provisions could become obstacle without additional Congressional action. The financial arrangements associated with arrears clearance and debt relief will require U.S. support, including both financial and

\footnotetext{
${ }^{43}$ These conditions include: (1) restoration of the rule of law in Zimbabwe; (2) certain election or pre-election conditions have been met; (3) the Government has demonstrated a commitment to an equitable, legal, and transparent land reform program that is consistent with agreements reached at the International Donors' Conference on Land Reform and Resettlement in Zimbabwe in September 1998; (4) the Government is making a good faith effort to fulfill the terms of the Lusaka Agreement that ended the Congo war; and (5) Zimbabwean state security services have become subordinate to the elected civilian Government.

${ }^{44}$ The U.S. Executive Directors are appointed by the President and confirmed by the Senate. They are the official representative of the United States at each institution. In practical terms, the Executive Directors receive guidance from and report to the Under Secretary for International Affairs at the U.S. Treasury Department, also a position confirmed by the U.S. Senate.

${ }^{45}$ The United States has the following voting shares: (a) IMF - 16.77 percent; (b) World Bank/IBRD - 16.4 percent; (c) World Bank/IDA - 12.1 percent; (d) African Development Bank - roughly 9 percent; and (e) African Development Fund 6.5 percent.
} 
political. As such, the ZDERA's legislative restrictions will need to be removed beforehand. There are two ways to eliminate the relevant restrictions. First, President Obama can certify that the specific preconditions have been met. However, the current conditions in Zimbabwe likely would prevent such a certification. For example, the Obama Administration would have a difficult time arguing that: (a) rule of law has been restored; (b) the government is committed to equitable, legal, and transparent land reform; and/or (c) state security forces are subordinate to the civilian government. Alternatively, the U.S. Congress could repeal the legislation or pass new legislation that supersedes ZDERA. Either way, this is an important obstacle that must be addressed with the Obama Administration and the $111^{\text {th }}$ Congress. 